\title{
In-vitro Assessment of Bisphenol a Release from Orthodontic Retainers
}

\author{
Authors informations \\ - Author names: \\ Abdelali HALIMI ${ }^{1}$, Bony Lama ${ }^{1}$, Amine Cheikh $^{2}$, Fatima Zaoui ${ }^{1}$
}

- Affiliations:

${ }^{1}$ Department of Orthodontics and Dentofacial Orthopedics, Faculty of Dentistry, Mohammed-V University (UM5) in Rabat, Research Team of Biotech., Ibn Sina Hospital, Rabat City, Morocco.

${ }^{2}$ Department of Bioequivalence and research, Cheikh Zaid Foundation, International University of Health Sciences Abulcasis (UIASS), Rabat City, Morocco.

Corresponding author:

Abdelali HALIMI: Professor in Orthodontic, Specialist in Orthodontics, PhD, Department of Orthodontics and Dentofacial Orthopedics, Faculty of Dentistry, Mohammed-V University

(UM5) in Rabat, Research Team of Biotech., Ibn Sina Hospital, Rabat City, Morocco.

Full postal address:

University Mohammed V, Faculty of Dentistry institutes PB 6212 Rabat, Morocco. Ibn Sina Hospital" CHIS. Tel: +212666285639

Authors details:

1. Abdelali HALIMI: Professor in Orthodontic, Specialist in Orthodontics, PhD, Department of Orthodontics and Dentofacial Orthopedics, Faculty of Dentistry, Mohammed-V University

(UM5) in Rabat, Research Team of Biotech., Ibn Sina Hospital, Rabat City, Morocco.

2. Bony Lama: Specialist in Orthodontics, Department of Orthodontics and Dentofacial Orthopedics, Faculty of Dentistry, Mohammed-V University (UM5) in Rabat, Research Team of Biotech., Ibn Sina Hospital, Rabat City, Morocco.

3. Amine Cheikh: specialist in biology. Department of Bioequivalence and research, Cheikh Zaid Ibn Foundation, International University of Health Sciences Abulcasis (UIASS), Rabat City, Morocco.

4. Fatima Zaoui: Professor of Higher Education in orthodontics, department head of Orthodontics and Dentofacial Orthopedics, Faculty of Dentistry, Mohammed-V University (UM5) in Rabat, Research Team of Biotech., Ibn Sina Hospital, Rabat City, Morocco.

doi: 10.51505/ijmshr.2021.5601

URL: http://dx.doi.org/10.51505/ijmshr.2021.5601 


\title{
International Journal of Medical Science and Health Research
}

Vol. 5, No. 06; 2021

ISSN: 2581-3366

\begin{abstract}
Background: The adhesives used to bond lingual bonded retainers are low-loaded composite resins with a resinous matrix containing bisphenol $\mathrm{A}$ and other molecules. To investigate and quantify the release of BPA from these retainers.
\end{abstract}

Methods: Three types of orthodontic bond were selected randomly from the most popular orthodontic composites: Transbod XT, Master-Dent ${ }^{\circledR}$ Flow and Nanocomposite Proclinic Expert. Specimens were made using a metallic parallelepiped mold and polymerized for 20 seconds with an LED lamp. Each cured sample was immediately immersed in artificial saliva with different $\mathrm{pH}$ levels $(7,4,2)$. Samples were analyzed at t0, t1 and t2 using a HighPerformance Liquid Chromatography. Data were analyzed using a statistical package for social sciences. One-factor Anova and Anova for repeated measurements tests were used. A value of $p$ less than 0.05 was considered statistically significant.

Results: The analyses showed BPA release from Proclinic, although both Transbond XT and Master-Dent ${ }^{\circledR}$ didn't show any release of BPA in saliva $(p>0.05)$. Release from Proclinic was influenced by the $\mathrm{pH}$ of medium $(\mathrm{p}<0.05)$ and the immersion time $(\mathrm{p}<0.05)$, thereby the more the $\mathrm{pH}$ decreased the more the amount of BPA increased $(\mathrm{p}<0.05)$ and as the immersion time increased the amount of BPA increased $(\mathrm{p}<0.05)$. The maximum amount of BPA reached from Proclinic was $0.680 \mu \mathrm{g} / \mathrm{ml}$ and $1.032 \mu \mathrm{g} / \mathrm{ml}$ at $\mathrm{t} 2-\mathrm{Ph} 4$ and $\mathrm{t} 2-\mathrm{Ph} 2$ respectively.

Conclusions: The different amounts of BPA released from Proclinicremain relatively lower than the tolerable daily intake of BPA, but clinicians should be careful about the use of composites.

Keywords: Bisphenol A, Composites resin, Fixed retainers, In-vitro study, Orthodontic

\section{Introduction}

Currently, it is accepted that a retention phase is essential for stability of orthodontic treatment results and the application of a suitable retention method is important both for prevention of relapse and for increasing patient satisfaction[1]. Bonded lingual retainers have been used in orthodontics since the 1970s. These retainers are composed generally of metallic wires bonded to enamel with an adhesive [2,3]. Seen the complications related with lingual bonded retainers during the retention period, the retainers werekeptin mouth as long as possible[1,4]. The adhesives used to bond orthodontic retentions are low-loaded composite resins with a resinous matrix containing bisphenol A (BPA) and various other molecules. BPAis a synthetic component used in the manufacture of plastics since the 1950s[5]. This component is widely used in the dental practice. In fact, BPA and its derivatives are present in almost $80 \%$ of the composites used in dentistry [5]. Many prospective studies have focused on the biological effects generally observed in animals, especially at the endocrine level [6,7]. Carcinogenic effects [8,9], on the brain and behavior [10-13]. On obesity [14,15], on diabetes [16,17], on the cardiovascular system [18-21]. on the immune system and the enamel of teeth [22-24]. The tolerable daily intake (TDI) of BPA was reduced from 50 to $4 \mathrm{mg} / \mathrm{kg} / \mathrm{day}$ in 2015 . BPA is banned for food contact in some European countries [25-26]. 


\section{International Journal of Medical Science and Health Research}

Vol. 5, No. 06; 2021

ISSN: 2581-3366

In order to improve our practice and to protect the health of our patients during the retention period, we wanted to investigate and quantify the possible release of BPA from orthodontic bond used for fixed retainer.

\section{Materials and Methods}

Three types of orthodontic bond manufactured by different companies were selected randomly from the most popular orthodontic composites used in our clinic for bonding orthodontic wire retainers: Transbod XT (3M Unitek, Monrovia, Calif, USA), Master-Dent ${ }^{\circledR}$ Flow (Dentonics Inc, Monroe, USA) and Nanocomposite Proclinic Expert(CHL Medical solutions, Cavallotti, Milán - Italia). Composite samples were made using metallic parallelepiped molds (length of $18 \mathrm{~mm}$, thickness of $8 \mathrm{~mm}$ )to better simulate the quantity of adhesive applied toan orthodontic retainer. Each sample was cured for 20seconds using a curing light with a LED lamp of $1000 \mathrm{mw} / \mathrm{cm} 2$ respecting a minimal distance of $1 \mathrm{~mm}$ between the light and the composite[27]. Each cured sample was immediately immersed in a solution of artificial saliva at different $\mathrm{pH}$ levels $(\mathrm{pH} 7, \mathrm{pH} 4$, and $\mathrm{pH} 2)$ for 1 hour in a glass tube at $37^{\circ} \mathrm{C}$. The saliva formula used for this study was Saliveze [28,29], a therapeutic artificial saliva whose properties are close to those of real human saliva (Table 1). A total of 27 samples were analyzed att $0, \mathrm{t} 1$ and $\mathrm{t} 2$ (Table 2) using a High-Performance Liquid Chromatography (HPLC). Thus, in each glass tube of $1 \mathrm{ml}$ of saliva, $1 \mathrm{ml}$ of acetonitril was added, then passed through a magnetic stirrer (vortex) for $15 \mathrm{secs}$, the mixture was centrifuged at $1600 \mathrm{rpm}$ for $8 \mathrm{~min}$ with a temperature of $6^{\circ} \mathrm{C}$. The supernatant was filtered with a $0.2 \mu \mathrm{m}$ laying cellulose filter. Each $20 \mu \mathrm{L}$ of filtered solution was injected into the HPLC system for analysis. The characteristics of the HPLC used are as follows: a phenomenex synergi type column $(150 * 2 \mathrm{~mm} ; 4 \mu \mathrm{m})$, a mobile phase $\mathrm{H} 2 \mathrm{O} /$ Acetonitrile, a flow rate of $0.5 \mathrm{ml} / \mathrm{min}$, a column temperature at $35^{\circ} \mathrm{C}$, the injection volume wasat $20 \mu \mathrm{l}$ and the detector was fluorescent with $\lambda \mathrm{ex}=230 \mathrm{~nm}$ and $\lambda \mathrm{em}=316 \mathrm{~nm}$.

\section{Statistical Analysis}

The descriptive statistic of the items investigated obtained from the initial, tland t2were presented. Quantitative values with a normal distribution are presented as means and standard deviation $(\mathrm{M} \pm \mathrm{SD})$. Data were processed using the statistical package for social sciences, Onefactor Anova test was carried out to compare the statistical means between the different independent groups. Anova test for repeated measurements was executed to compare the statistical means between the different matched groups. A value of $\mathrm{P}$ less than 0.05 was considered statistically significant.

\section{Results}

The quantitative and qualitative analyses showed no BPA release from both Transbond XT and Master-Dent ${ }^{\circledR}$ in artificial saliva at the 3 level of $\mathrm{pH}$ between $\mathrm{t} 0$ and $\mathrm{t} 2(\mathrm{p}>0.05)$. A variable release of BPA was observed with Proclinic. The descriptive analysis and statistical comparisons of BPA release between the composites studied is presented intable $3 \mathrm{a}$ and $\mathrm{b}$. Figures 1,2 and 3showed BPA release curve from the different composites. Release from Proclinic was influenced by the $\mathrm{pH}$ of medium $(\mathrm{p}<0.05)$ and the immersion time $(\mathrm{p}<0.05)$, thereby the more the $\mathrm{pH}$ decreased the more the amount of BPA increased $(\mathrm{p}<0.05)$ and as the immersion time 


\section{International Journal of Medical Science and Health Research}

Vol. 5, No. 06; 2021

ISSN: 2581-3366

increased the amount of BPA increased $(\mathrm{p}<0.05)$. The maximum amounts of BPA reached in saliva from Proclinic was $0.680 \mu \mathrm{g} / \mathrm{ml}$ and $1.032 \mu \mathrm{g} / \mathrm{ml}$ at t1 $-\mathrm{Ph} 2$ and $\mathrm{t} 2-\mathrm{Ph} 2$ respectively (table 3 ).

\section{Discussion}

We followed the gold standards for sample preparation, material selection and biological testing. Liquid phase chromatography and mass spectrometry showed release of BPA in Proclinic, although both Transbond XT and Master-Dent ${ }^{\circledR}$ showed no BPA release in artificial saliva with the 3 level of $\mathrm{pH}$ between $\mathrm{t} 0$ and $\mathrm{t} 2$ ( $\mathrm{p}>0.05)$. Release from Proclinic was influenced by the $\mathrm{pH}$ of medium $(\mathrm{p}<0.05)$ and the immersion time $(\mathrm{p}<0.05)$. The maximum amounts of BPA reached in saliva from Proclinic was $0.680 \mu \mathrm{g} / \mathrm{ml}$ and $1.032 \mu \mathrm{g} / \mathrm{ml}$ at $\mathrm{t} 1-\mathrm{Ph} 2$ and $\mathrm{t} 2-\mathrm{Ph} 2$ respectively. A comparison of published results was limited because there are diversity of protocols and inhomogeneity of methods analysis.

Our study did not show the release of BPA from Transbond XT. This result agrees withBationo et al [30], they didn't observe any release of BPA from Transbond XT, Transbond LV and MonoLok 2 in a Milli-Q water solution using a gas phase chromatography and mass spectrometry (GCMS) with a detection threshold of $0.02 \mathrm{ppm}$. They didn't study Master-Dent ${ }^{\circledR}$ and Proclinic but they highlighted the release of BPA from the Blugloo adhesive. Our result agrees also with Pelourde et al[31], they also didn't observe release from Transbond XT and Transbond LR above the detection threshold of $0.02 \mathrm{ppm}$ using a GCMSmethod. But they highlighted the release of monomers and particularly TEGDMA from Transbond XT and Transbond LR, and the release of others several potentially toxic compounds. Our result agrees toowithEliades et al[32] and Malkiewicz et al[33]. Malkiewicz [33] didn't detect BPA in Transbond XT after 1 hour, 24 hours, 7 days and 31 days of material sample storage in water using the HPLC method, but the Resilence released $32.10 \mathrm{ppm}$ of BPA at 1 hour. Eliades[31]didn't observe any release from Rely-a-bond and Reliance above a detection threshold of $0.1 \mathrm{ppm}$ using a HPLC method at 1, 7, 21, 35 days of immersion in a pure alcohol solution medium.

However,regarding Transbond XT our result didn'tagree with Sunitha et al[34], Purushothaman et al[35],Eliades et al [36],Deviot et al[37], Kotyk and Wiltshire[38].

Sunitha[34] detected measurable amounts of BPA in all samples of Transbond XT at 1, 7, 21, and 35 days above a detection threshold of $0.1 \mathrm{ppm}$ using a HPLC method; the maximum amount found reached $65.67 \mathrm{ppm}$ at 21 days. The BPA release from Transbond XTwas greater when the composite was cured with a greater light-curing tip distance. Purushothaman[35] founded that, the light-emitting diode device (LED) demonstrated significantly less BPA release. The chemically cured group showed significantly less BPA release. Among the light-cured composites, those cured according to the manufacturers' recommendations released less BPA than did the self-etching primer and the moisture insensitive primer. Eliades[34]confirmed these results by identifying measurable amounts of BPA in all groups of Transbond XT studied in a double-distilled water for Immersion medium, using a GCMS method; with the highest found in 


\section{International Journal of Medical Science and Health Research}

Vol. 5, No. 06; 2021

ISSN: 2581-3366

the immersion media of the 1-month groups, whereas the control (tooth storage solution) had $0.16 \mathrm{mg} / \mathrm{L}$.

Deviot[37]confirmed this result by detecting the BPA in all samples from Transbond XT stored in three extraction media: artificial saliva, acetonitrile and methanol, using a GCMS method. But, with liquid chromatography/mass spectrometry, BPA was detected only from samples immersed in methanol; Bis-GMA was detected, in varying amount according to the extraction media and the light-curing time. BPA was found after heating of the Bis-GMA solution. Kotyk and Wiltshire [38]observed BPA release from Transbond XT immerged in Artificial saliva of $0.34 \mathrm{ppm}$ at 3 days using a GCMS method.

Our study showed the release of BPA in Proclinic, although LCMC showed no release of BPA from Master-Dent ${ }^{\circledR}$ in artificial saliva with the 3 level of $\mathrm{pH}$ between $\mathrm{t} 0$ and $\mathrm{t} 2$. A comparison of published results was impossible because there are no studies in literature about these composites. Kang [39] founded a significant high level of BPA from Filtek Flow (nanohybridfilled flowable resin) and Z250 Universal Restorative (hybrid-filled restorative resin) in the saliva collected just after placement of the lingual bonded retainer light-cured by using a plasma xenon arc light curing unit (wavelength, 450-500 nm; intensity, $1900 \mathrm{mw} / \mathrm{cm} 2$ ) by radiating the occlusal and gingival surfaces of the resin for 3 seconds each. Flowable resin had lower BPA levels than those in the conventional hybrid resin. This result was performed using a HPLC method.

To minimize exposure for patient and staff to BPA, Eliades [40] suggested same measures like bonding with glass-ionomer cements; request details on BPA; optimize polymerization conditions (sufficient light exposure times, close proximity of tip to bracket and adequate light intensity); have the patient rinse with copious amount of water after bonding; use a sufficient adhesive hardness. For Debonding, Select a bracket base mesh-adhesive filler content combination that results in a resin cohesive/enamel-adhesive fracture, remove as much material as possible without using rotary instruments, during resin grinding have access to fresh air, use surgical suction and masks for all staff pregnant staff and operators must avoid continuous and long-term exposure to the aerosols produced during debonding, operatories with multiple dental units in the same area (open-bay plan) must allow sufficient space between chairs and avoid scheduling concurrent debonding appointments in multiple chairs[41,42]. Additional research is needed to determine the magnitude of change from pre-to post-dental treatment and the trajectory of uBPA concentrations posttreatment.[43] Purushothaman [35] suggested curing time should be according to the manufacturer's recommendations. These steps will ensure less BPA release and a greater degree of conversion. Sunitha [34] suggested the clinicians should ensure that the adhesive is completely cured by keeping the light-curing tip as close to the adhesive as clinically possible.

\section{Conclusion}

Under the conditions of this study, the analysis of the three orthodontic bonds used for fixed retainers allows us to highlighted the absence of BPA release from both Transbond XT and 


\section{International Journal of Medical Science and Health Research}

Vol. 5, No. 06; 2021

ISSN: 2581-3366

Master-Dent ${ }^{\circledR}$ in artificial saliva at the 3 level of $\mathrm{pH}$ between $\mathrm{t} 0$ and $\mathrm{t} 2$. A variable release of BPA was observed with Proclinic. Release from Proclinic was influenced by the $\mathrm{pH}$ of medium and the immersion time $(\mathrm{p}<0.05)$. The maximum amount of BPA reached from Proclinic was $1.032 \mu \mathrm{g} / \mathrm{ml}$ in saliva, $\mathrm{Ph} 2$ after 1 hour. The different amounts observed remain relatively lower than the reference dose for daily ingestion. The results of this study might have significant clinical implications by showing a variable BPA release from Proclinic influenced medium that can overcome some of the limitations of study. Clinicians should be careful about the type of composite used and must follow the guidelines of good practice.

Sources of support: This research did not receive any sources of support, any specific grant from funding agencies in the public, commercial, or not-for-profit sectors.

Disclosure of interest: The authors declare that they have no conflicts of interest concerning this article.

Acknowledgments: The authors would like to thank MmeBouchafra from the institute of Bioequivalence and research, Cheikh Zaid Ibn Foundation for help.

\section{References}

Kartal Y, Kaya B. Fixed Orthodontic Retainers: A Review.Turk J Orthod. 2019 Jun;32(2):110114.

Pandis N, Vlahopoulos K, Madianos P, Eliades T. Long term periodontal status of patients with mandibular lingual fixed retention. Eur J Orthod2007;29:471-6.

Iliadi A, KloukosD, Gkantidis N, Katsaros C, Pandis N. Failure of fixed orthodontic retainers: a systematic review. J Dent 2015;43:876-96.

Tae-Kyung Kim, Seung-HakBaek.Lingual bonded retainers: A case series of complications and resolutions. APOS Trends in Orthodontics. 2020. 10(1); 3-11.

Halimi A, Benyahia H, Bahije L, Adli H, Azeroual MF, Zaoui F. A systematic study of the release of bisphenol A by orthodontic materials and its biological effects.Int Orthod. 2016 Dec;14(4):399-417.

Fenichel P, Chevalier N, Brucker-Davis F. Bisphenol A: an endocrine and metabolic disruptor. Ann Endocrinol (Paris). 2013 Jul;74 (3):211-20.

Mileva G, Baker SL, Konkle AT, Bielajew C. Bisphenol A: epigenetic reprogramming and effects on reproduction and behavior. Int J Environ Res Public Health. 2014 Jul 22;11 (7):7537-61.

Tarapore P, Ying J, Ouyang B, Burke B, Bracken B, Ho SM. Exposure to bisphenol A correlates with early-onset prostate cancer and promotes centrosome amplification and anchorageindependent growth in vitro.PLoS One. 2014 Mar 3;9(3):e90332. 


\section{International Journal of Medical Science and Health Research}

Vol. 5, No. 06; 2021

ISSN: 2581-3366

Gao H1, Yang BJ, Li N, Feng LM, Shi XY, Zhao WH, Liu SJ. Bisphenol A and hormoneassociated cancers: current progress and perspectives. Medicine (Baltimore). 2015 Jan;94 (1):e211.

Tang WY, Morey LM, Cheung YY, Birch L, Prins GS, Ho SM. Neonatal exposure to estradiol/bisphenol A alters promoter methylation and expression of Nsbp1 and Hpcall genes and transcriptional programs of Dnmt $3 \mathrm{a} / \mathrm{b}$ and $\mathrm{Mbd} 2 / 4$ in the rat prostate gland throughout life. Endocrinology. 2012 Jan;153(1):42-55.

Richter CA, Birnbaum LS, Farabollini F, Newbold RR, Rubin BS, Talsness CE, Vandenbergh JG, Walser-Kuntz DR, vom Saal FS. In vivo effects of bisphenol A in laboratory rodent studies.ReprodToxicol. 2007 Aug-Sep;24(2):199-224.

Elsworth JD1, Jentsch JD, Vandevoort CA, Roth RH, Redmond DE Jr, Leranth C. Prenatal exposure to bisphenol A impacts midbrain dopamine neurons and hippocampal spin synapses in non-human primates. Neurotoxicology. 2013 Mar;35:113-20.

Kelly EA, Opanashuk LA, Majewska AK. The effects of postnatal exposure to low-dose bisphenol-A on activity dependent plasticity in the mouse sensory cortex. Front Neuroanat. 2014 Oct 22;8:117.

Harley KG, Aguilar Schall R, Chevrier J, Tyler K, Aguirre H, Bradman A, Holland NT, Lustig RH, Calafat AM, Eskenazi B. Prenatal and postnatal bisphenol A exposure and body mass index in childhood in the CHAMACOS cohort. Environ Health Perspect. 2013 Apr;121(4):514-20.

Trasande L, Attina TM, Blustein J. Association between urinary bisphenol A concentration and obesity prevalence in children and adolescents. JAMA. 2012 Sep 19;308(11):1113-21.

Vom Saal FS, Nagel SC, Coe BL, Angle BM, Taylor JA. The estrogenic endocrine disrupting chemical bisphenol A (BPA) and obesity. Mol Cell Endocrinol. 2012 May 6;354(1-2):7484.

Seltenrich N. A Hard Nut to Crack: Reducing Chemical Migration in Food-Contact Materials. Environ Health Perspect. 2015 Jul;123(7): A174-9.

Talsness CE, Andrade AJ, Kuriyama SN, Taylor JA, vom Saal FS. Components of plastic: experimental studies in animals and relevance for human health.Philos Trans R Soc Lond B Biol Sci. 2009 Jul 27;364(1526):2079-96.

Bae S, Kim JH, Lim YH, Park HY, Hong YC. Associations of bisphenol A exposure with heart rate variability and blood pressure.Hypertension. 2012 Sep;60(3):786-93.

Shankar A, Teppala S. Urinary bisphenol A and hypertension in a multiethnic sample of US adults. J Environ Public Health. 2012;2012:481641.

Shankar A, Teppala S, Sabanayagam C. Bisphenol A and peripheral arterial disease: results from the NHANES. Environ Health Perspect. 2012 Sep;120(9):1297-300. 


\section{International Journal of Medical Science and Health Research}

Vol. 5, No. 06; 2021

ISSN: 2581-3366

Calafat AM, Kuklenyik Z, Reidy JA, Caudill SP, Ekong J, Needham LL. Urinary concentrations of bisphenol A and 4-nonylphenol in a human reference population. Environ Health Perspect. 2005 Apr;113(4):391-5.

O'Brien E, Dolinoy DC, Mancuso P. Perinatal bisphenol A exposures increase production of proinflammatory mediators in bone marrow-derived mast cells of adult mice. $\mathrm{J}$ Immunotoxicol. 2014 Jul-Sep;11(3):205-12.

Bodin J, Bølling AK, Becher R, Kuper F, Løvik M, Nygaard UC. Transmaternal bisphenol A exposure accelerates diabetes type 1 development in NOD mice. Toxicol Sci. 2014 Feb;137(2):311-23.

European Information Centre on bisphenol A. Food Contact Regulation: Available at: http://www.bisphenol-a-europe.org/en_GB/ legislation/food-contact. Accessed December 11, 2016.

European Food Safety Authority. Opinion of the scientific panel on food additives, flavourings, processing aids and materials in contact with food on a request from the commision related to 2,2-bis(4-hydroxyphenyl) propane (bisphenol A). Question number EFSA-Q2005-100. EFSA Jounal2006;428:1-75.

Kloukos D, Pandis N, Eliades T. Bisphenol-A and residual monomer leaching from orthodontic adhesive resins and polycarbonate brackets: a systematic review. Am J Orthod Dentofacial Orthop 2013;143(Suppl 4):S104-12.

Halimi A, Azeroual MF, Doukkali A, El Mabrouk K, Zaoui F. Elastomeric chain force decay in artificial saliva: an in vitro study. Int Orthod. 2013 Mar;11(1):60-70.

Preetha A, Banerjee R. Comparison of artificial saliva substitutes. Trends BiomaterArtif Organs 2005;8(2):178-86.

BationoR, Jordana F, Boileau MJ, Colat-Parros J. Release of monomers from orthodontic adhesives. Am J Orthod Dentofacial Orthop2016;150:491-8.

Pelourde C, Bationo R, Boileau MJ, Colat-Parros J, Jordana F. Monomer release from orthodontic retentions: An in vitro study. Am J Orthod Dentofacial Orthop. 2018 Feb;153(2):248-254.

Eliades T, Hiskia A, Eliades G, Athanasiou AE. Assessment of bisphenol-A release from orthodontic adhesives. Am J OrthodDentofacial Orthop2007;131:72-5.

Malkiewicz K, Turło J, Marciniuk-Kluska A, Grzech-Le_sniakK, GaÎsior M, Kluska M. Release of bisphenol A and its derivatives from orthodontic adhesive systems available on the European market as a potential health risk factor. Ann Agric Environ Med 2015;22:1727.

Sunitha C, Kailasam V, Padmanabhan S, Chittaranjan AB. Bisphenol A release from an orthodontic adhesive and its correlation with the degree of conversion on varying lightcuring tip distances. Am J Orthod Dentofacial Orthop2011;140:239-44. 
Vol. 5, No. 06; 2021

ISSN: 2581-3366

Purushothaman D, Kailasam V, Chitharanjan AB. Bisphenol A release from orthodontic adhesives and its correlation with the degree of conversion. Am J Orthod Dentofacial Orthop. 2015 Jan;147(1):29-36.

Eliades T, Voutsa D, Sifakakis I, Makou M, Katsaros C. Release of bisphenol-A from a lightcured adhesive bonded to lingual fixed retainers. Am J Orthod Dentofacial Orthop2011;139:192-5.

Kang YG, Kim JY, Kim J, Won PJ, Nam JH. Release of bisphenol A from resin composite used to bond orthodontic lingual retainers. Am J Orthod Dentofacial Orthop. 2011 Dec;140(6):779-89.

Deviot M, Lachaise I, Högg C, Durner J, Reichl FX, Attal JP, Dursun E. Bisphenol A release from an orthodontic resin composite: A GC/MS and LC/MS study. Dent Mater. 2018 Feb;34(2):341-354.

Kotyk M, Wiltshire WA. An investigation into bisphenol-A leaching from orthodontic materials. Angle Orthod2014;84:516-20.

Eliades T. Bisphenol A and orthodontics: An update of evidence-based measures to minimize exposure for the orthodontic team and patients.

Am J Orthod Dentofacial Orthop. 2017 Oct;152(4):435-441.

Day CJ, Price R, Sandy JR, Ireland AJ. Inhalation of aerosols produced during the removal of fixed orthodontic appliances: a comparison of 4 enamel cleanup methods. Am J Orthod Dentofacial Orthop2008;133:11-7.

Kloukos D, Sifakakis I, Voutsa D, Doulis I, Eliades G, Katsaros C, et al. BPA qualtitative and quantitative assessment associated with orthodontic bonding in vivo. Dent Mater 2015;31:887-94.

T. Marzouk, S.Sathyanarayana, A.S. Kim, A.L. Seminario, C.M. McKinney. A Systematic Review of Exposure to Bisphenol A from Dental Treatment. JDR Clin Trans Res. 2019 Apr; 4(2): 106-115 
Vol. 5, No. 06; 2021

ISSN: 2581-3366

\section{Figures}
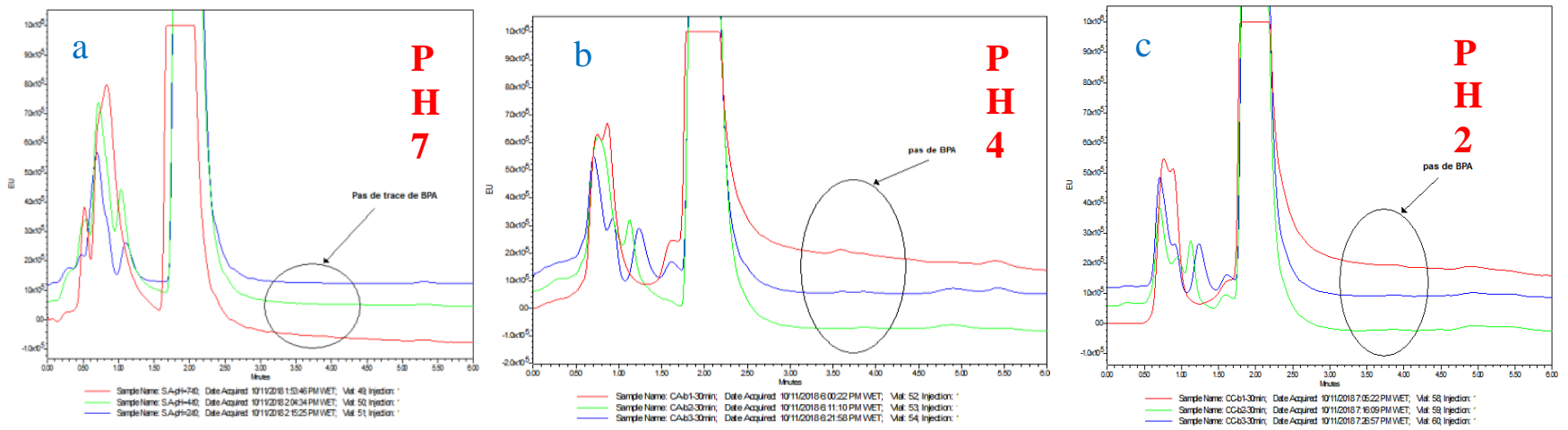

Fig. 1. Release of BPA from the Transbond $\mathbf{X T}$ in artificial saliva at $\mathrm{pH} 7$ (a), $\mathrm{pH} 4$ (b) and $\mathrm{pH} 2$ (c)
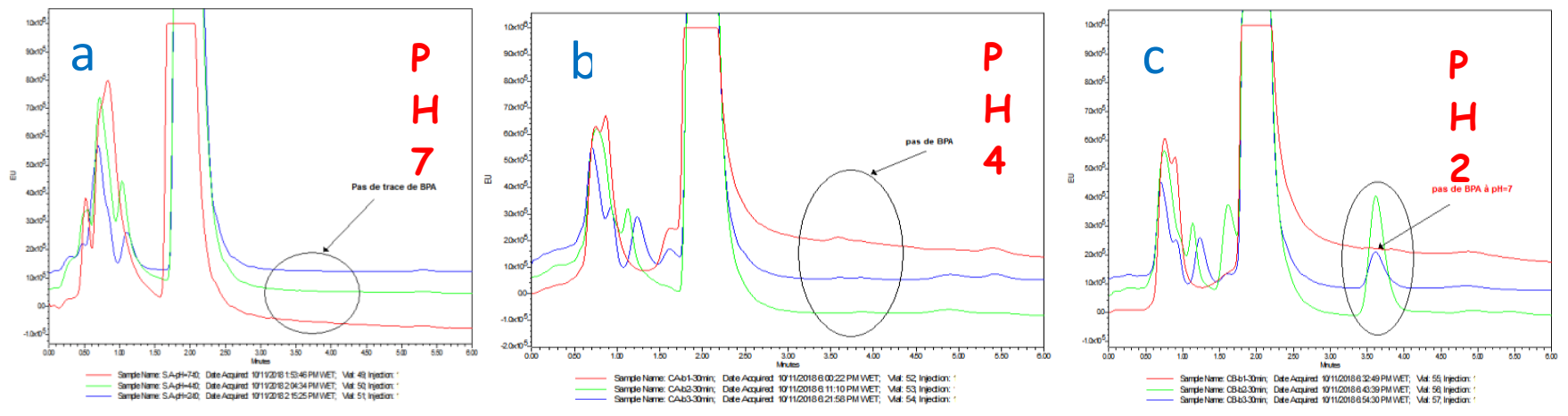

Fig. 2. Release of BPA from the Master-Dent ${ }^{\circledR}$ in artificial saliva at $\mathrm{pH} 7$ (a), $\mathrm{pH} 4$ (b) and $\mathrm{pH} 2$ (c)
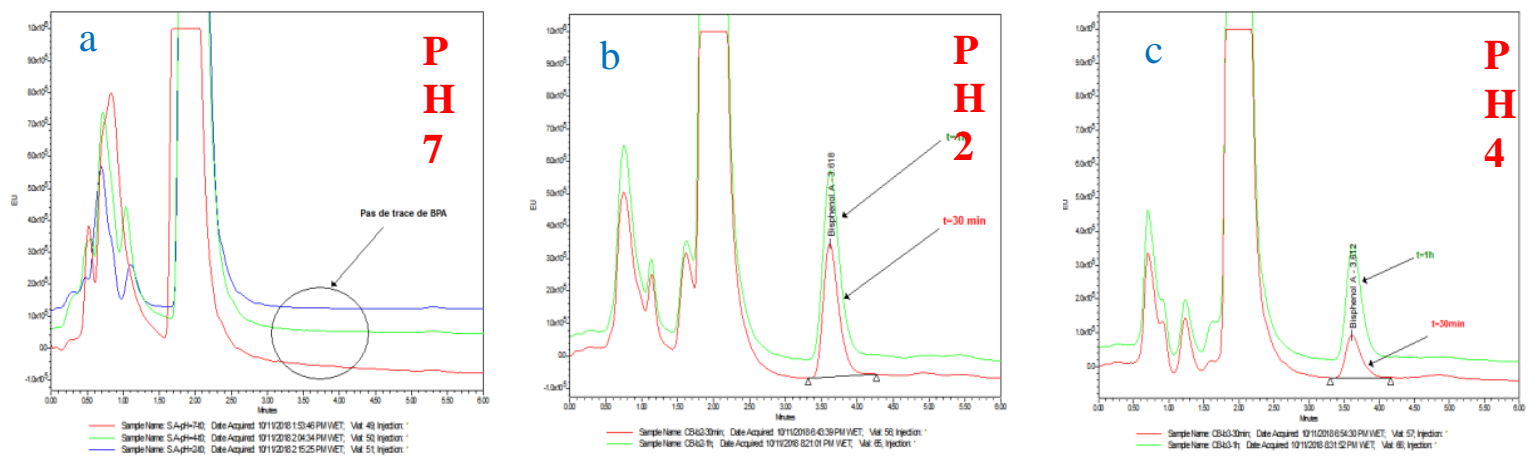

Fig. 3. Release of BPA from the Proclinic in artificial saliva at $\mathrm{pH} 7$ (a), $\mathrm{pH} 4$ (b) and $\mathrm{pH} 2$ (c) 
International Journal of Medical Science and Health Research

Vol. 5, No. 06; 2021

ISSN: 2581-3366

Table 1: Saliveze formula, borrowed from Preetha and Banerjee.

\begin{tabular}{|l|c|}
\hline \multicolumn{1}{|c|}{ Component } & Quantity en g/L/ \\
\hline Sodium carboxymethylcellulose & 10 \\
\hline Potassium chloride & 0.62 \\
\hline Sodium chloride & 0.87 \\
\hline Magnesiumchloride & 0.06 \\
\hline Calcium chloride & 0.17 \\
\hline Di-potassium hydrogenorthophosphate & 0.80 \\
\hline Potassium di-hydrogenorthophosphate & 0.30 \\
\hline Sodium fluoride & 0.0044 \\
\hline Sorbitol & 29.95 \\
\hline Methyl p-hydroxybenzoate & 1.00 \\
\hline Spirit of lemon & $5 \mathrm{~mL}$ \\
\hline
\end{tabular}

Table 2: The different samples of composites under study

\begin{tabular}{|l|l|c|c|c|c|}
\hline Code & \multicolumn{1}{|c|}{ Company (type) } & PH & Time & Sample & Total of sample \\
\hline I & Transbond XT & PH7 & T0(0mm) & 9 & \\
\hline II & Proclinic Nanohybrid “Expert" & PH4 & T1(30mn) & 9 & 27 \\
\hline III & Master-Dent ${ }^{\circledR}$ Flow Composite & PH2 & T2(1h) & 9 & \\
\hline
\end{tabular}




\section{International Journal of Medical Science and Health Research}

Vol. 5, No. 06; 2021

ISSN: 2581-3366

Tables 3: Statistical comparisons of the amount of BPA $(\mu \mathrm{g} / \mathrm{ml})$ released by the three composites studied depending of time and the $\mathrm{pH}$ of the immersion medium

\begin{tabular}{|c|c|c|c|c|}
\hline & \multicolumn{3}{|c|}{ pH7 } & \multirow[b]{2}{*}{$\mathrm{p}$ value } \\
\hline & t0 (Initial) & $\mathrm{t} 1(30 \mathrm{mn})$ & t2 (1h) & \\
\hline 3M Unitek, n=9 & $0.000001 \pm 0.000001$ & $0.000003 \pm 0.000004$ & $0.000004 \pm 0.000001$ & 0.6 \\
\hline Proclinic, $n=9$ & $0.000015 \pm 0.000001$ & $0.000020 \pm 0.000004$ & $0.000025 \pm 0.000003$ & 0.5 \\
\hline \multirow[t]{3}{*}{ Master-Dent, $\mathrm{n}=9$} & $0.000011 \pm 0.000001$ & $0.000013 \pm 0.000004$ & $0.000015 \pm 0.000002$ & 0.4 \\
\hline & \multicolumn{3}{|c|}{$\mathrm{pH} 4$} & \\
\hline & t0 (Initial) & $\mathrm{t} 1(30 \mathrm{mn})$ & t2 (1h) & $\mathrm{p}$ value \\
\hline 3M Unitek $(\mathrm{n}=9)$ & $0.00001 \pm 0.000001$ & $0.00001 \pm 0.000004$ & $0.000014 \pm 0.000005$ & 0.5 \\
\hline Proclinic $(n=9)$ & $0.00014 \pm 0.00005$ & $0.198 \pm 0.051$ & $0.561 \pm 0.031$ & $0.000^{*}$ \\
\hline \multirow[t]{3}{*}{$\begin{array}{l}\text { Master-Dent } \\
(\mathrm{n}=9)\end{array}$} & $0.00001 \pm 0.000001$ & $0.00001 \pm 0.000004$ & $0.000012 \pm 0.000005$ & 0.6 \\
\hline & \multicolumn{3}{|c|}{$\mathrm{pH} 2$} & \\
\hline & t0 (Initial) & $\mathrm{t} 1(30 \mathrm{mn})$ & $\mathrm{t} 2(1 \mathrm{~h})$ & $\mathrm{p}$ value \\
\hline 3M Unitek $(n=9)$ & $0.00001 \pm 0.000001$ & $0.00001 \pm 0.000002$ & $0.000014 \pm 0.000003$ & 0.6 \\
\hline Proclinic $(\mathrm{n}=9)$ & $0.00015 \pm 0.00005$ & $0.680 \pm 0.02$ & $1.032 \pm 0.04$ & $0.000^{*}$ \\
\hline $\begin{array}{l}\text { Master-Dent } \\
(\mathrm{n}=9)\end{array}$ & $0.00001 \pm 0.000001$ & $0.00001 \pm 0.000004$ & $0.000014 \pm 0.000005$ & 0.5 \\
\hline
\end{tabular}

a: One-factor Anova test: *: statistically significant because $\mathrm{p}$ less than 0.05

\begin{tabular}{|c|c|c|c|c|c|c|}
\cline { 2 - 7 } \multicolumn{1}{c|}{} & \multicolumn{2}{c|}{ 3M Unitek $(\mathrm{n}=9)$} & \multicolumn{2}{c|}{ Proclinic $(\mathrm{n}=9)$} & \multicolumn{2}{c|}{ Master-Dent $(\mathrm{n}=9)$} \\
\cline { 2 - 7 } \multicolumn{1}{c|}{} & Groups appariés & $\mathrm{p}$ value & Groups appariés & $\mathrm{p}$ value & Groups appariés & $\mathrm{p}$ value \\
\hline \multirow{2}{*}{$\mathrm{pH} 7$} & $\mathrm{t} 0-\mathrm{t} 1$ & 0.5 & $\mathrm{t} 0-\mathrm{t} 1$ & 0.6 & $\mathrm{t} 0-\mathrm{t} 1$ & 0.5 \\
\cline { 2 - 7 } & $\mathrm{t} 1-\mathrm{t} 2$ & 0.7 & $\mathrm{t} 1-\mathrm{t} 2$ & 0.6 & $\mathrm{t} 1-\mathrm{t} 2$ & 0.7 \\
\hline \multirow{2}{*}{$\mathrm{pH} 4$} & $\mathrm{t} 0-\mathrm{t} 1$ & 0.5 & $\mathrm{t} 0-\mathrm{t} 1$ & $0.000^{*}$ & $\mathrm{t} 0-\mathrm{t} 1$ & 0.5 \\
\cline { 2 - 7 } & $\mathrm{t} 1-\mathrm{t} 2$ & 0.7 & $\mathrm{t} 1-\mathrm{t} 2$ & $0.000^{*}$ & $\mathrm{t} 1-\mathrm{t} 2$ & 0.7 \\
\hline \multirow{2}{*}{$\mathrm{pH} 2$} & $\mathrm{t} 0-\mathrm{t} 1$ & 0.5 & $\mathrm{t} 0-\mathrm{t} 1$ & $0.000^{*}$ & $\mathrm{t} 0-\mathrm{t} 1$ & 0.5 \\
\cline { 2 - 7 } & $\mathrm{t} 1-\mathrm{t} 2$ & 0.7 & $\mathrm{t} 1-\mathrm{t} 2$ & $0.000^{*}$ & $\mathrm{t} 1-\mathrm{t} 2$ & 0.7 \\
\hline
\end{tabular}

b: Anova test for repeated measurements, *: statistically significant because $\mathrm{p}$ less than 0.05 